\title{
Evaluation of the Modulatory Effects of Copper Salts on the Process of Angiogenesis (Neovascularization) with Therapeutic Perspectives
}

\author{
Rekha Khandia ${ }^{1}$, Pratibha Vishwakarma ${ }^{1}$, Abhinav Dwivedi ${ }^{1}$, Reena Mehra ${ }^{1}$, Anshumala \\ KuJur $^{1}$, Kuldeep Dhama ${ }^{2}$, Ashok Munjal ${ }^{1 *}$
}

\section{${ }^{1}$ Department of Genetics, Barkatullah University, Bhopal-462 026 (M.P.), India; ${ }^{2}$ Division of Pathology, Indian Veterinary Research Institute, Izatnagar, Bareilly-243 122 (Uttar Pradesh), India.}

\begin{abstract}
Angiogenesis is a vital physiological process of formation and development of new blood vessels (neovascularization) from pre-existing ones, essential for embryonic development and growth especially in the growing stages. Copper $(\mathrm{Cu})$ is known to promote angiogenic factors like VEGF (Vascular Endothelial Growth Factor), FGF (Fibroblast growth factor), angiopoitin and others, and as per previous reports, depending upon the material, $\mathrm{Cu}$ sometimes inhibit angiogenesis. We investigated the effects of different $\mathrm{Cu}$ salts (Copper chloride, copper acetate, alkaline copper tartrate and copper carbonate) on the process of angiogenesis among chicken chorioallantoic membrane (CAM) model by assessing histopathological alterations. Out of the four $\mathrm{Cu}$ salts studied, copper carbonate was found to be pro-angiogenic and did not reveal any detrimental effect, and therefore can have potential to be explored as a therapeutic material under health conditions requiring neovascularization. Rest other $\mathrm{Cu}$ salts (Copper chloride, copper acetate and alkaline copper tartrate) investigated were anti-angiogenic and induced inflammation in experimental material. Observing the importance of $\mathrm{Cu}$ in neovascularization, its salts can be used in therapeutic strategy either for treating disorders caused by excess angiogenesis or reduced angiogenesis.
\end{abstract}

Keywords | Angiogenesis, Neovascularization, Endothelial cells, Chorioallantoic membrane, Copper salts, Therapy

Editor | Yashpal S. Malik, Indian Veterinary Research Institute, Uttar Pradesh, India.

Received | June 30, 2016; Accepted | July 12, 2016; Published | July 22, 2016

*Correspondence | Ashok Munjal, Department of Genetics, Barkatullah University Bhopal-462 026 (M.P.), India; Email: ashokmunjal70@yahoo.co.in

Citation | Khandia R, Vishwakarma P, Dwivedi A, Mehra R, Kujur A, Dhama K, Munjal A (2016). Evaluation of the modulatory effects of copper salts on the process of Angiogenesis (Neovascularization) with therapeutic perspectives. Adv. Anim. Vet. Sci. 4(8): 405-410.

DOI | Http://dx.doi.org/10.14737/journal.aavs/2016/4.8.405.410

ISSN (Online) | 2307-8316; ISSN (Print) | 2309-333

Copyright $\odot 2016$ Khandia et al. This is an open access article distributed under the Creative Commons Attribution License, which permits unrestricted use, distribution, and reproduction in any medium, provided the original work is properly cited.

\section{INTRODUCTION}

$\mathrm{T}$ The term 'angiogenesis' refers to formation and development of new blood vessels (neovascularization) from the pre-existing ones (Birbrair et al., 2014; 2015). It is a multi-step and complex physiological process, essential for development (Yoo and Kwon, 2013), growth (Van Lessen et al., 2015) and wound healing (Johnson and Traci, 2014). Both excessive and insufficient angiogenesis conditions are responsible for pathological interventions. Excessive angiogenesis is associated with disorders like diabetic retinopathy (Praidou et al., 2010), cancer (Dudek et al., 2012), arthritis (Elshabrawy et al., 2015), age related macular degeneration ( $\mathrm{Ng}$ and Adamis, 2005) etc. Insufficient blood supply in case of reduced angiogenesis imposes the risk of tissue death in several diseases such as ischemic chronic wound (Frykberg and Banks, 2015) and coronary artery diseases (Kastrup, 2010). It is also required for bone integration and survival in fracture repair (Saran et al., 2014).

Copper $(\mathrm{Cu})$ is supposed to have pro-angiogenic activity owing to activation of pro-angiogenic growth factors and promoting endothelial cell migration, growth, and tube formation (Saghiri et al., 2015). It stimulates various factors viz. vascular endothelial growth factor (VEGF), fibroblast growth factor-2 (FGF2), tumor necrosis factor (TNF)- $\alpha$ and platelet-derived endothelial cell growth factor (PDECGF), which are responsible for pro-angiogenic effects (Gupte and Mumper, 2009). It is also required for the activation and expression of hypoxia-inducible factor-1 (HIF1), a major transcription factor, responsible for regulating the expression of VEGF (Xie and Kang, 2009). Cu is also associated with cell migration, invasion, proliferation and 
the formation of tubular structures (Gao and $\mathrm{Xu}, 2008)$.

Copper or copper salts have been reported to increase angiogenesis among several model systems viz. bovine aorta endothelial cell system (McAuslan et al., 1983), rabbit corneal system (Raju et al., 1982), in vivo (Alessandri et al., 1984; Sanaat et al., 2011; Mroczek-Sosnowska et al. $2015)$ etc. $\mathrm{Cu}$ in the form of salt $\left(\mathrm{CuSO}_{4}\right)$ or nanoparticles, when introduced into chicken embryos did not interfere with embryonic growth or development, but has been shown to increase angiogenesis via increasing the mRNA of activators like VEGF and FGF (Mroczek-Sosnowska et al., 2015). Recently, in few reports, contradictory to previous findings, $\mathrm{Cu}$ has been found to be anti-angiogenic too (Chang et al., 2015; Gandin et al., 2015). Hence, it necessitates evaluating different $\mathrm{Cu}$ salts for defining their pro-angiogenic or anti-angiogenic effects. The present study aimed to elucidate the angiogenic modulating effects of four $\mathrm{Cu}$ salts [Copper chloride, $\mathrm{CuCl}_{2}$; copper acetate, $\mathrm{Cu}\left(\mathrm{CH}_{3} \mathrm{COO}\right)_{2}$; alkaline copper tartrate, $\mathrm{C}_{4} \mathrm{H}_{4} \mathrm{CuO}_{6}$; and copper carbonate, $\mathrm{CuCO}_{3}$ ] on chorioallantoic membrane (CAM) model of chicken.

\section{MATERIALS AND METHODS}

The four different $\mathrm{Cu}$ salts $\left[\mathrm{CuCl}_{2}, \mathrm{Cu}\left(\mathrm{CH}_{3} \mathrm{COO}\right)_{2}\right.$, $\mathrm{C}_{4} \mathrm{H}_{4} \mathrm{CuO}_{6}$ and $\mathrm{CuCO}_{3}$ ] were used in the present study. Their effects on the process of angiogenesis were evaluated using the chicken chorioallantoic membrane (CAM) model (Ribatti et al., 1997; Wierzbicki et al., 2013). The embryonated chicken eggs $(n=50)$ of 9 to 11 days of age, weighing around $61 \pm 3 \mathrm{~g}$ were procured from State poultry farm, Raisen Road, Bhopal (MP). The eggs were divided into five experiments groups (10 eggs in each), comprising of one control group (Group I) and four treatment groups (Group II- treated with copper chloride, Group III- treated with copper acetate, Group IV- treated with alkaline copper tartrate and Group V- treated with copper carbonate).

The egg surfaces were cleaned and wiped with $70 \%$ ethanol. A total of $200 \mu 1$ of $0.5 \mathrm{M}$ of each $\mathrm{Cu}$ salts $\left[\mathrm{CuCl}_{2}\right.$, $\mathrm{Cu}\left(\mathrm{CH}_{3} \mathrm{COO}\right)_{2}, \mathrm{C}_{4} \mathrm{H}_{4} \mathrm{CuO}_{6}$ and $\mathrm{CuCO}_{3}$ ] were directly introduced onto the CAM of respective group of embryonated eggs using 26 gauge hypodermic syringe along with antibiotic (Ampicillin $50 \mu \mathrm{g} / \mathrm{ml}$, Streptomycin $10 \mu \mathrm{g} / \mathrm{ml}$ ) and antimycotic solution (Amphotericin $10 \mu \mathrm{g} / \mathrm{ml}$ ). Control group received phosphate buffered saline (PBS) with antibiotic and antimycotic solution. The eggs were resealed with cellophane tape and incubated for $72 \mathrm{hrs}$ in a humid incubator chamber at $37^{\circ} \mathrm{C}$. The eggs were then opened to observe the effects of different copper salts for angiogenesis modulation. The CAM was observed and further it was harvested and subjected to histopathological analysis using Hematoxylin and Eosin stain.

\section{RESULTS}

The embryonated chicken eggs of all the five experimental groups were examined/ opened after $72 \mathrm{hrs}$ of incubation after treatment with different copper salts. Modulatory effects of different $\mathrm{Cu}$ salts on the process of angiogenesis by visualizing the gross and histopathological alterations in chorioallantoic membranes (CAMs) were observed.

The CAM of control group (Group I) revealed well arbourized vascular system, with several major and minor blood vessels (Figure 1A). In the case of copper chloride (Group II) and copper carbonate (Group V) treated groups, the blood vessels were observed as thin with less number of branch points (Figure 1B). In copper acetate treated group, CAM had more number of branch points with well noticed arbourization. Among alkaline copper tartrate treated group, CAM was firmly sticked with chalaza having less number of branch points and blood vessels.

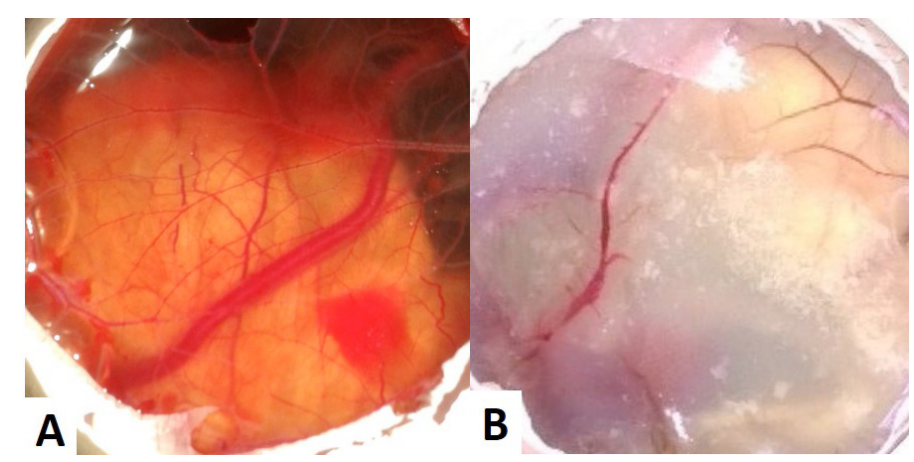

Figure 1: (A) CAM of control eggs (Group I) with well arbourized vascular system; (B) CAM of copper chloride treated eggs (Group II) showing thin blood vessels with less number of branch points

Histopathology of the control (Group I) revealed normal thickness of CAM, with concordant dispersed mesodermal blood vessels (BV) and vein (V) with loose connective tissue (Figure 2A). Whereas, copper chloride treated CAM (Group II) exhibited reduced size and number of major blood vessels, with dense fibroblast (FB) cells (Figure 2B). Copper acetate treated CAM (Group III) revealed uneven thickness, reduced thickness of allantoic epithelial membrane (AE), less number of major and minor blood vessels with densely accumulated fibroblast (FB) cells, indicative of inflammation in the tissue (Figure 2C). Among alkaline copper tartrate treated group (Group IV), irregular thickness of CAM, with reduced thickness of chorionic epithelium (CE) and dense fibroblast accumulation was observed (Figure 2D).

It has been observed that groups treated with copper acetate (Group III) and copper tartrate (Group IV) demonstrated the inverse patterns in reduction in thickening of $\mathrm{AE}$ and $\mathrm{CE}$. However, copper carbonate treated (Group V) 


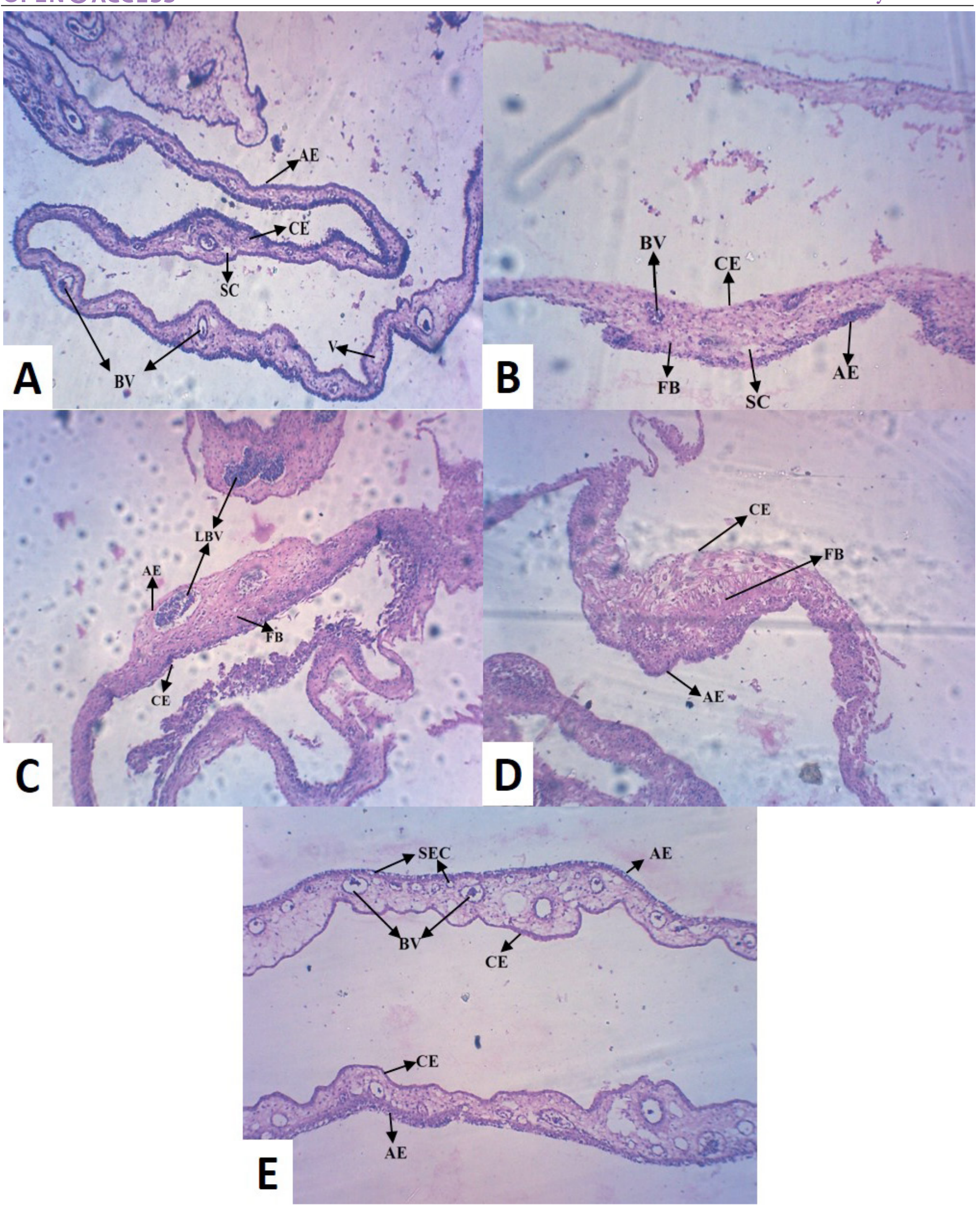

Figure 2: Histopathological analysis of CAM (100X) treated with different Cu salts (A) Control CAM showing mesodermal LBV with $\mathrm{SC}$ and $\mathrm{AE}$ and $\mathrm{CE}$ of equal thickness (B) Copper chloride treated CAM showing reduced thickness in CE (C) Copper acetate treated CAM showing hypodermic LBV and FB cells (D) Copper tartrate treated CAM showed thin AE, but no blood vessel and densely accumulated FB cells (E) Copper carbonate treated CAM showed numerous BV with SEC, indicative of pro-angiogenic activity [LBV (Large Blood Vessels); BV (Blood Vessels); V (Vein); AE (Allantoic Epithelium); CE (Chorionic Epithelium); FB (Fibroblast); SEC (Sub Epidermal Capillary plexus); SC (Small Capillary)] 
CAM was different from the other four groups, exhibiting large number of blood vessels $(\mathrm{BV})$ of mesodermal origin (Figure $2 \mathrm{E}$ ), which further converge to epidermis and formed sub-epidermal capillary (SEC) plexus, indicative of pro-angiogenic activity. It also did not alter normal morphology of CAM and unlike other treatment groups, did not caused tissue inflammation.

\section{DISCUSSION}

Angiogenesis is a vital process of growth and development and it is a delicate balance between pro-angiogenic and anti-angiogenic substances. Tissues get proper nourishment through the network of blood vessels, both excessive and deprived angiogenesis leads to pathological conditions. Gold (Arvizo et al., 2011) and silver (Khandia et al., 2015) nanoparticles are known to inhibit angiogenesis, whereas copper nanoparticles have been shown to have pro-angiogenic effect (Mroczek-Sosnowska et al., 2015). Cu acts as a stimulator of angiogenesis, vasculogenesis and endothelial cell migration by expressing angiogenic growth factors like VEGF, FGF and TNF (Finney et al., 2009). Angiogenin, a strong blood vessel formation inducer, binds to endothelial cell receptors to form new blood vessels, with 4.8 folds greater affinity in presence of $\mathrm{Cu}^{2+}$ (Soncin et al., 1997). Both, in form of $\mathrm{Cu}$ salt $\left(\mathrm{CuSO}_{4}\right)$ and metallic $\mathrm{Cu}(\mathrm{CuO})$, it exhibited pro-angiogenic activity (Mroczek-Sosnowska et al., 2015). After applying on HUVECs (Human Umbilical Vein Endothelial Cells), the alloy of $\mathrm{Cu}$ with $\mathrm{Mg}$ revealed more number of branch points and a more complex morphology of angiogenesis (Liu et al., 2016).

On one side, $\mathrm{Cu}$ is increasing angiogenesis, whereas on the other side, some $\mathrm{Cu}$ compounds are known to have anti-angiogenic activity. Chang et al. (2015) revealed that $\mathrm{CuO}$ nanoparticles down-regulated the expression of vascular endothelial growth factor (VEGF) and VEGF receptors in endothelial cells. Homoleptic phosphino copper (I) complexes also repressed angiogenesis by inhibiting the fundamental steps of blood vessel formation like endothelial cell adhesion, migration, alignment, protease secretion and tubule formation (Chang et al., 2015; Gandin et al., 2015). The reason behind the contradictory behaviour can be explained on the basis of nature of material used for study, like solubility, ionic strength, dissociation constant and $\mathrm{pH}$ change in microenvironment surrounding the affected area.

Therefore, it became important to evaluate several $\mathrm{Cu}$ compounds for their pro- or anti-angiogenic activity. Locally available $\mathrm{Cu}$ levels are found to regulate the growth or regression of new blood vessels (Mroczek-Sosnowska et al., 2015). The extracellular $\mathrm{Cu}$ may directly bind to endothelial cell receptors and in turn it can stimulate a number of intracellular signaling pathways including PI3K (phosphoinositide 3-kinase)/ Akt, which is associated with up-regulation of survivin (apoptosis inhibitor) in endothelial cells and protection of endothelium from death-inducing stimuli (Papapetropoulos et al., 2000). Cu transporter proteins i.e. copper-transporting ATP7A and 7B (ATPase $\alpha$-polypeptide and $\beta$-polypeptide) and high affinity copper uptake protein (Copper transporter 1, CTR1), help in maintaining homeostasis of copper (Singleton et al., 2010).

The uptake of $\mathrm{Cu}$ by CTR1 is temperature and $\mathrm{pH}$ dependent (Lee et al., 2002). However, the exact mechanism of transport is unknown. Here in the present study, we investigated four $\mathrm{Cu}$ salts (the $\mathrm{pH}$ order was $\mathrm{CuCl} 2<$ $\left.\mathrm{Cu}\left(\mathrm{CH}_{3} \mathrm{COO}\right)_{2}<\mathrm{CuCO}_{3}<\mathrm{C}_{4} \mathrm{H}_{4} \mathrm{CuO}_{6}\right)$; and used alkaline copper tartrate as very basic ( $\mathrm{pH} 10.0$ ), and copper chloride as acidic ( $\mathrm{pH} 4.0)$. Therefore, it can be assumed that these solutions must have created a microenvironment, which was not suitable for proper functioning of CTR1 and also the $\mathrm{pH}$ adversely affected the CAM cells and hence inflammation occurred. The same also resulted in the induction of dense fibroblast accumulation with reduced vascularization in copper tartrate and copper chloride treated CAM. Our results are in agreement with the earlier studies of Badarau and Dennison (2011); demonstrated that ATP7A transporters are dependent upon $\mathrm{pH}$ and the transporter affinity is decreased approximately 5 -fold, when the $\mathrm{pH}$ was lowered from 7-8 to 6.1. The acidic $\mathrm{pH}$ alters the status of charge onto the amino acids present in transporter proteins. Acidic $\mathrm{pH}$ could alter the charge status of the amino acids, for example, histidine residue of ATP7A activated tyrosinase in the active site, where charge alteration might modify the incorporation of the metal ion into active site and inappropriate incorporation could be assumed (Bin et al., 2015).

In a zebra fish model, after exposure, the accumulation of $\mathrm{Cu}$ nanoparticles (CUO) and $\mathrm{CuCl}_{2}$ in zebra fish larvae and ZFL (zebrafish cell line) was compared, despite using high nanoparticle concentration (5:1 in in vitro and 3:1 in vivo, respectively) the degree of accumulation of $\mathrm{Cu}$ was not much different (Chang et al., 2015). It indicated that accumulation is not dependent on extracellular $\mathrm{Cu}$ concentration. Therefore the deciding factor remains the affinity of $\mathrm{Cu}$ with ion transporter proteins, which in turn is dependent on dissociation of $\mathrm{Cu}$ compounds to release $\mathrm{Cu}$ ions and surrounding $\mathrm{pH}$. Copper carbonate $(\mathrm{pH} 6)$ and copper acetate ( $\mathrm{pH} 6.5)$, should efficiently bind to the transporter, but copper acetate ( $\mathrm{pH} 6.5)$ also revealed inflammation and angiogenesis inhibition due to unexplained reasons. Copper carbonate $(\mathrm{pH}$ 6) showed pro-angiogenic activity, as it did not affected ATP7A transporter activity and Copper accumulated in cytosol might have helped in expressing pro-angiogenic factors like VEGF, FGF and angiopoitins, resulted in increased angiogenesis (Figure 3). Hence, copper carbonate can be used as pro-angiogenic material. 


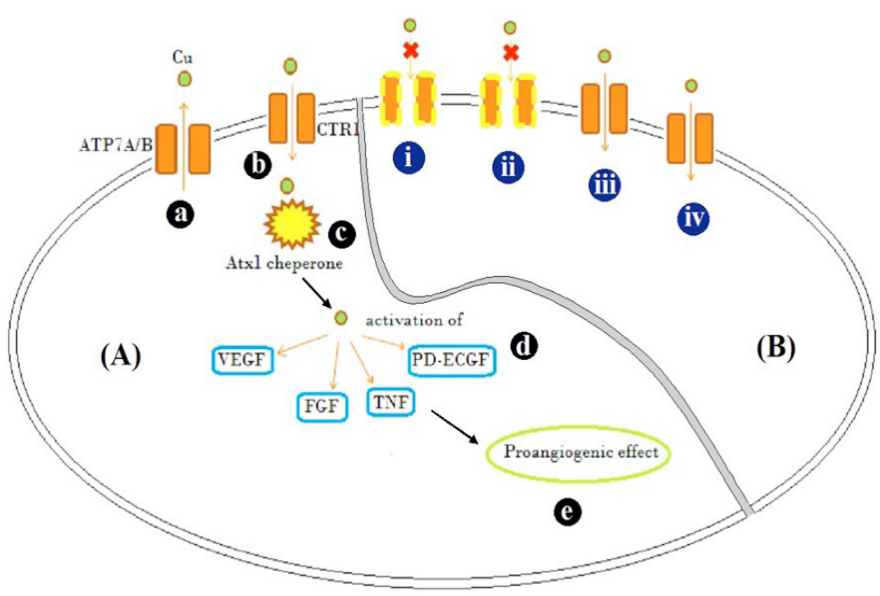

Figure 3: Schematic representation of [A] Mode of action of $\mathrm{Cu}$ traffic; (a) ATP7A/ B are $\mathrm{Cu}$ transporter proteins regulating intracellular $\mathrm{Cu}$ concentration (b) CTR1 is Cu uptake protein (c) Atx1, a $\mathrm{Cu}$ uptake protein which is responsible for intracellular $\mathrm{Cu}$ binding and trafficking and release of $\mathrm{Cu}$ activates (d) VEGF, FGF, TNF and PD-ECGF growth factors (e) resulting in proangiogenic effect. [B] Illustration of possible mechanism by which different $\mathrm{Cu}$ salts altered angiogenesis and tissue pathophysiology (i) $\mathrm{CuCl}_{2}$, (acidic) and (ii) $\mathrm{C}_{4} \mathrm{H}_{4} \mathrm{CuO}_{6}$ (basic), possibly inactivated copper transporters by altering the net charge on them and showed inflammatory response evident by accumulation of fibroblast cells (Figure 2B and D) (iii) $\mathrm{Cu}\left(\mathrm{CH}_{3} \mathrm{COO}\right)_{2}$ resulted in $\mathrm{Cu}$ transport mediated anti-angiogenesis, but caused inflammation too (Figure 2C) (iv) $\mathrm{CuCO}_{3}$ allowed entry of $\mathrm{Cu}$ and acted as pro-angiogenic material

Currently, many pathological conditions like rheumatoid arthritis, chronic wound and coronary artery diseases etc., which arose from the reduced angiogenic condition, are treated with pro-angiogenic therapies. Copper carbonate could be a promising pro-angiogenic material and need to be evaluated further to be used as therapeutics.

\section{CONCLUSIONS}

$\mathrm{Cu}$ in form of salt $\left(\mathrm{CuSO}_{4}\right)$, metallic $\mathrm{Cu}(\mathrm{CuO}), \mathrm{Cu}$ alloy $(\mathrm{Cu}-\mathrm{Mg})$ and $\mathrm{Cu}$ nanoparticle, has shown to modulate angiogenic activity. It has shown both the sides of the coin, pro-angiogenic as well as anti-angiogenic activities; hence it is essential to evaluate different $\mathrm{Cu}$ compounds to observe which compound reveal what kind of activity. Here in the present study, copper acetate, copper chloride, and alkaline copper tartrate behaved as anti-angiogenic compounds, but caused inflammation in the CAM tissue, hence are not good for anti-angiogenic treatment. Copper carbonate, exhibited pro-angiogenic effect, with no detrimental effect on tissue and therefore could be a potential candidate for therapies requiring increased angiogenesis. Further the pro-angiogenic activity of copper carbonate may be tested in complex model systems (viz. rat corneal assay) or experimentally induced chronic wound or rheumatoid arthritis among animals.

\section{ACKNOWLEDGMENTS}

Financial assistance from DBT-IPLS is gratefully acknowledged. Authors of the manuscript thank and acknowledge their respective Universities/ Institutes.

\section{CONFLICTS OF INTEREST}

The authors declare that no conflict of interest.

\section{AUTHOR'S CONTRIBUTION}

Pratibha Vishwakarna and Anshumala Kujur executed the experimental work, Abhinav Dwivedi and Reena Mehra assisted in histology and collection of literature, Rekha Khandia and Ashok Munjal designed the study, interpreted the results and written the manuscript, Kuldeep Dhama reviewed the manuscript.

\section{REFERENCES}

-Alessandri G, Raju K, Gullino PM (1984). Angiogenesis in vivo and selective mobilization of capillary endothelium in vitro by heparin-copper complex. Microcirc. Endothelium Lymphatics. 1: 329-346.

-Arvizo RR, Rana S, Miranda OR, Bhattacharya R, Rotello VM, Mukherjee P (2011). Mechanism of anti-angiogenic property of gold nanoparticles: role of nanoparticle size and surface charge. Nanomedicine. 7(5): 580-587. http://dx.doi. org/10.1016/j.nano.2011.01.011

-Badarau A, Dennison C (2011). Copper Trafficking Mechanism of CXXC-Containing Domains: Insight from the $\mathrm{pH}$ Dependence of Their $\mathrm{Cu}(\mathrm{I})$ Affinities. J. Am. Chem. Soc. 133: 2983-2988. http://dx.doi.org/10.1021/ja1091547

-Bin B, Bhin J, Yang SH, Shin M, Nam Y, Choi D, Shin DW, Lee A, Hwang D, Cho E, and Lee TR (2015). MembraneAssociated Transporter Protein (MATP) Regulates Melanosomal $\mathrm{pH}$ and Influences Tyrosinase Activity. PLoS One. 10(6): e0129273. http://dx.doi.org/10.1371/journal. pone.0129273

- Birbrair A, Zhang T, Wang ZM, Messi ML, Mintz A, Delbono O (2015). Pericytes at the intersection between tissue regeneration and pathology. Clin. Sci.128(2): 81-93. http:// dx.doi.org/10.1042/CS20140278

- Birbrair A, Zhang T, Wang ZM, Messi ML, Olson JD, Mintz A, Delbono O (2014). Type-2 pericytes participate in normal and tumoral angiogenesis. Am. J. Physiol. Cell Physiol. 307(1): C25-38. http://dx.doi.org/10.1152/ ajpcell.00084.2014

- Chang J, Ichihara G, Shimada Y, Tada-Oikawa S, Kuroyanagi J, Zhang B, Suzuki Y, Sehsah R, Kato M, Tanaka T, Ichihara S (2015). Copper Oxide Nanoparticles Reduce Vasculogenesis in Transgenic Zebrafish Through Down-Regulation of Vascular Endothelial Growth Factor Expression and Induction of Apoptosis. J. Nanosci. Nanotechnol. 15(3): 2140-2147. http://dx.doi.org/10.1166/jnn.2015.9762

-Dudek AZ, Gupta K, Ramakrishnan S, Mukhopadhyay D (2012). Tumor Angiogenesis. J. Oncol. 2012: 857383.

-Elshabrawy HA, Chen Z, Volin MV, Ravella S, Virupannavar 
S, Shahrara S (2015). The pathogenic role of angiogenesis in rheumatoid arthritis. Angiogenesis. 18(4): 433-448. http:// dx.doi.org/10.1007/s10456-015-9477-2

- Finney L, Vogt S, Fukai T, Glesne D (2009). Copper and angiogenesis: unravelling a relationship key to cancer progression. Clin. Exp. Pharmacol. Physiol. 36(1): 88-94. http://dx.doi.org/10.1111/j.1440-1681.2008.04969.x

- Frykberg R, Banks J (2015). Challenges in the Treatment of Chronic Wounds. Adv. Wound Care (New Rochelle). 4(9): 560-582. http://dx.doi.org/10.1089/wound.2015.0635

- Gandin V, Trenti A, Porchia M, Tisato F, Giorgetti M, Zanusso I, Trevisia L, C Marzano (2015). Homoleptic phosphino copper(I) complexes with in vitro and in vivo dual cytotoxic and anti-angiogenic activity. Metallomics. 7: 1497-1507. http://dx.doi.org/10.1039/C5MT00163C

- Gao X, Xu Z (2008). Mechanisms of action of angiogenin. Acta Biochim. Biophys. 40(7): 619-624. http://dx.doi. org/10.1007/s00707-007-0481-5

- Gupte A, Mumper RJ (2009). Elevated copper and oxidative stress in cancer cells as a target for cancer treatment. Cancer Treat. Rev. 35(1): 32-46. http://dx.doi.org/10.1016/j. ctrv.2008.07.004

-Johnson KE, Traci A (2014). WilgusVascular Endothelial Growth Factor and Angiogenesis in the Regulation of Cutaneous Wound Repair. Adv. Wound Care. (New Rochelle). 3(10): 647-661. http://dx.doi.org/10.1089/ wound.2013.0517

-Kastrup J, (2010). Gene therapy and angiogenesis in patients with coronary artery disease. Expert Rev. Cardiovasc. Ther. 8(8): 1127-1138. http://dx.doi.org/10.1586/erc.10.95

-Khandia R, Munjal A, Bangrey RS, Mehra R, Dhama K, Sharma NC (2015). Evaluation of silver nanoparticle mediated reduction of neovascularisation (angiogenesis) in chicken model. Adv. Anim. Vet. Sci. 3(7): 372-376. http://dx.doi. org/10.14737/journal.aavs/2015/3.7.372.376

-Lee J, Pena MM, Nose Y, Thiele DJ (2002). Biochemical characterization of the human copper transporter Ctr1. J. Biol. Chem. 277: 4380-7. http://dx.doi.org/10.1074/jbc. M104728200

-Liu C, Fu X, Pan H, Wan P, Wang L, Tan L, Wang K, Zhao Y, Yang K, Chu PK (2016). Biodegradable Mg-Cu alloys with enhanced osteogenesis, angiogenesis, and long-lasting antibacterial effects. Scientific Reports 6, Article number: 27374. http://dx.doi.org/10.1038/srep27374

-McAuslan BR, Reilly WG, Hannan GN, Gole GA (1983). Angiogenic factors and their assay: activity of formyl methionyl leucyl phenylalanine, adenosine diphosphate, heparin, copper, and bovine endothelium stimulating factor. Microvasc. Res. 26(3): 323-338. http://dx.doi. org/10.1016/0026-2862(83)90080-8

-Mroczek-Sosnowska N, Sawosz E, Vadalasetty KP, Łukasiewicz M, Niemiec J, Wierzbicki M, Kutwin M, Jaworski S, Chwalibog A (2015). Nanoparticles of Copper Stimulate Angiogenesis at Systemic and Molecular Level. Int. J. Mol. Sci. 16(3): 4838-4849. http://dx.doi.org/10.3390/ ijms16034838

- Ng EW, Adamis AP (2005). Targeting angiogenesis, the underlying disorder in neovascular age-related macular degeneration. Can. J. Ophthalmol. 40(3): 352-368. http://

\section{dx.doi.org/10.1016/S0008-4182(05)80078-X}

-Papapetropoulos A, Fulton D, Mahboubi K, Kalb RG, O'Connor DS, Li F, Altieri DC, Sessa WC (2000). Angiopoietin-1 inhibits endothelial cell apoptosis via the Akt/survivin pathway. J. Biol. Chem. 275(13): 9102-9105. http://dx.doi. org/10.1074/jbc.275.13.9102

- Praidou A, Androudi S, Brazitikos P, Karakiulakis G, Papakonstantinou E, Dimitrakos S. (2010). Angiogenic growth factors and their inhibitors in diabetic retinopathy. Curr. Diabetes Rev. 6(5): 304-312. http://dx.doi. org/10.2174/157339910793360815

- Raju KS, Alessandri G, Ziche M, Gullino PM (1982). Ceruloplasmin, copper ions, and angiogenesis. J. Natl. Cancer Inst. 69(5): 1183-1188.

- Ribatti D, Gualandris A, Bastaki M, Vacca A, Iurlaro M, Roncali L, Presta M (1997). New model for the study of angiogenesis and antiangiogenesis in the chick embryo chorioallantoic membrane: the gelatin sponge/chorioallantoic membrane assay. J. Vasc. Res. 34(6): 455-463. http://dx.doi. org/10.1159/000159256

- Saghiri MA, Asatourian A, Orangi J, Sorenson CM, Sheibani N (2015). Functional role of inorganic trace elements in angiogenesis-Part II: Cr, Si, Zn, Cu, and S. Crit. Rev. Oncol. Hematol. 96(1): 143-55. http://dx.doi.org/10.1016/j. critrevonc.2015.05.010

-Sanaat Z, Nouri M, Hajipour B, Dolatkhah R, Asvadi I, Vaez J, Eivazi J, Nikanfar A, Esfahani A, Chavoshi SH, Biorani $\mathrm{H}$ (2011). Evaluation of Copper, Zinc, $\mathrm{Cu} / \mathrm{Zn}$, and VEGF in Patients with AML in Iran. Iran J. Cancer Prev. Autumn. 4(4): 151-153.

- Saran U, Gemini Piperni S, Chatterjee S (2014). Role of angiogenesis in bone repair. Arch. Biochem. Biophys. 561: 109-117. http://dx.doi.org/10.1016/j.abb.2014.07.006

- Singleton WC, McInnes KT, Cater MA, Winnall WR, McKirdy R, Yu Y, Taylor PE, Ke BX, Richardson DR, Mercer JF, La Fontaine S (2010). Role of glutaredoxin1 and glutathione in regulating the activity of the copper-transporting P-type ATPases, ATP7A and ATP7B. J. Biol. Chem. 285(35): 27111-27121. http://dx.doi.org/10.1074/jbc.M110.154468

-Soncin F, Guitton JD, Cartwright T, Badet J (1997). Interaction of human angiogenin with copper modulates angiogenin binding to endothelial cells. Biochem. Biophys. Res. Commun. 236: 604-610. http://dx.doi.org/10.1006/ bbrc.1997.7018

- Van Lessen M, Nakayama M, Kato K, Kim JM, Kaibuchi K, Adams RH (2015). Regulation of vascular endothelial growth factor receptor function in angiogenesis by numb and numb-like. Arterioscler Thromb. Vasc. Biol. 35(8):18151825. http://dx.doi.org/10.1161/ATVBAHA.115.305473

-Wierzbicki M, Sawosz E, Grodzik M, Prasek M, Jaworski S, Chwalibog A (2013). Comparison of anti-angiogenic properties of pristine carbon nanoparticles. Nanoscale Res. Lett. 8(1):195.http://dx.doi.org/10.1186/1556-276X-8-195

-Xie H, Kang YJ (2009). Role of copper in angiogenesis and its medicinal implications. URR Med. Chem. 16(10): 13041314. http://dx.doi.org/10.2174/092986709787846622

-Yoo SY, Kwon SM (2013). Angiogenesis and Its Therapeutic Opportunities. Mediators Inflammation. (Volume 2013): $1-11$. 